\title{
Effect of Hydrogen Peroxide and Phosphate Addition on Biopolymers Formation and Changes in Head Loss in Biological Activated Carbon Process
}

\author{
Heejong Son ${ }^{\dagger \oplus} \cdot$ Eun-Young Jung ${ }^{\oplus} \cdot$ Hee-Young Kim ${ }^{\oplus}$. Sang-Goo Kim ${ }^{\oplus}$ \\ Water Quality Institute, Busan Water Authority
}

(Received October 28, 2020; Revised November 27, 2020; Accepted December 8, 2020)

Objectives: The purpose of this study was to suggest a more efficient operation condition for the BAC (biological activated carbon) process by evaluating the change in the concentration of biopolymers in the effluent of the BAC process and the head loss of the BAC filter layer according to phosphate $\left(\mathrm{PO}_{4}-\mathrm{P}\right)$ and hydrogen peroxide $\left(\mathrm{H}_{2} \mathrm{O}_{2}\right)$ input.

Methods : During the experiment period (Feb. to Aug. 2020), the $\mathrm{O}_{3}$ dosage was fixed at $1 \mathrm{mg} \cdot \mathrm{O}_{3} / \mathrm{mg} \cdot \mathrm{DOC}$. Four columns with an inner diameter of $20 \mathrm{~cm}$ and a height of $250 \mathrm{~cm}$ were prepared. Empty bed contact time (EBCT) was fixed at 20 minutes and backwash was performed once a week. The four BAC columns are conventional BAC (control-BAC), enhanced BAC with hydrogen peroxide $\left(\mathrm{H}_{2} \mathrm{O}_{2}+\mathrm{BAC}\right)$, enhanced BAC with phosphate $\left(\mathrm{PO}_{4}-\mathrm{P}+\mathrm{BAC}\right)$, and enhanced $\mathrm{BAC}$ with phosphate and hydrogen peroxide together $\left(\mathrm{PO}_{4}-\mathrm{P}+\mathrm{H}_{2} \mathrm{O}_{2}+\mathrm{BAC}\right)$. In the case of enhanced $\mathrm{BAC}$ with $\mathrm{PO}_{4}-\mathrm{P}$ added, $\mathrm{PO}_{4}-\mathrm{P}$ was added with a concentration of $0.010 \mathrm{mg} / \mathrm{L}$ in the influent, and in $\mathrm{BAC}$ with $\mathrm{H}_{2} \mathrm{O}_{2}, \mathrm{H}_{2} \mathrm{O}_{2}$ was added with a concentration of $1 \mathrm{mg} / \mathrm{L}$ to the influent.

Results and Discussion: According to the change of water temperature, the average head loss in control-BAC was $4.4\left(25 \sim 28^{\circ} \mathrm{C}\right) \sim 7.7 \mathrm{~cm}\left(8 \sim 12^{\circ} \mathrm{C}\right)$. In addition, $\mathrm{PO}_{4}-\mathrm{P}+\mathrm{BAC}, \mathrm{H}_{2} \mathrm{O}_{2}+\mathrm{BAC}$ and $\mathrm{PO}_{4}-\mathrm{P}+\mathrm{H}_{2} \mathrm{O}_{2}+\mathrm{BAC}$ were $3.9 \sim 5.8 \mathrm{~cm}$, $2.5 \sim 3.5 \mathrm{~cm}$, and $2.6 \sim 3.5 \mathrm{~cm}$, respectively. The head loss was reduced by the input of $\mathrm{PO}_{4}-\mathrm{P}$ and $\mathrm{H}_{2} \mathrm{O}_{2}$. During the low water temperature period, in control-BAC, the effluent biopolymers (BP) concentration was higher than the influent concentration, indicating that a large amount of EPS (extracellular polymeric substances) was produced and released from the attached biofilm. In $\mathrm{PO}_{4}-\mathrm{P}+\mathrm{BAC}, \mathrm{H}_{2} \mathrm{O}_{2}+\mathrm{BAC}$ and $\mathrm{PO}_{4}-\mathrm{P}+\mathrm{H}_{2} \mathrm{O}_{2}+\mathrm{BAC}$ processes, the $\mathrm{BP}$ concentration ratio $\left(\mathrm{C}_{\text {out }} / \mathrm{C}_{\text {in }}\right)$ was about $36 \sim 57 \%$ lower than that of the control-BAC during the low water temperature period. The $\mathrm{BP}$ concentration ratio was high when the water temperature $\left(8 \sim 12^{\circ} \mathrm{C}\right)$ was low, and the $\mathrm{BP}$ concentration ratio gradually decreased as the water temperature increased. These results were very similar to those of the head loss change in the control-BAC process and the enhanced BAC process, and the BP concentration ratio and the head loss showed a very high correlation $\left(r^{2}=0.82 \sim 0.87\right)$. To evaluate the stability of the biofilm during the operation period, the total cell counts (TCC) in $\mathrm{BAC}$ treated waters were investigated. In control-BAC, $\mathrm{PO}_{4}-\mathrm{P}+\mathrm{BAC}, \mathrm{H}_{2} \mathrm{O}_{2}+\mathrm{BAC}$ and $\mathrm{PO}_{4}-\mathrm{P}+\mathrm{H}_{2} \mathrm{O}_{2}+\mathrm{BAC}$ process, the average TCC was $46.8 \times 10^{6}$ cells, $30.3 \times 10^{6}$ cells, $21.8 \times 10^{6}$ cells, and $18.8 \times 10^{6}$ cells, respectively. Compared to the control-BAC, it was found to be $35 \sim 60 \%$ lower in the enhanced BAC processes. In addition, live cell count ( $\mathrm{LCC}$ ) ratio ( $\mathrm{LCC} / \mathrm{TCC}$ ) was $0.84 \sim 0.89$ in the enhanced BAC processes compared to 0.53 in the control-BAC. These results indicate that the biofilm stability of the enhanced BAC processes is higher than that of control-BAC.

Conclusions : During the experiment, compared to the conventional BAC process, the enhanced BAC processes in which $\mathrm{PO}_{4}-\mathrm{P}$ and $\mathrm{H}_{2} \mathrm{O}_{2}$ were added showed a clear effect of reducing the head loss. In particular, the effect of reducing the head loss was higher when $\mathrm{H}_{2} \mathrm{O}_{2}$ was added than when $\mathrm{PO}_{4}-\mathrm{P}$ was added. A rapid head loss increase occurred in the conventional BAC process compared to the enhanced $\mathrm{BAC}$ processes in the low water temperature season is the result of the production of large amounts of EPS in the attached biofilm. The input of $\mathrm{PO}_{4}-\mathrm{P}$ or $\mathrm{H}_{2} \mathrm{O}_{2}$ reduces the head loss by improving the stability of the attached biofilm and reducing EPS production.

Keywords : Biological Activated Carbon (BAC), Hydrogen Peroxide, Phosphate, Head Loss, Water Temperature, Biopolymers

The Korean text of this paper can be translated into multiple languages on the website of http://jksee.or.kr through Google Translator.

Corresponding author E-mail: menuturk@hanmail.net Tel: 051-669-4624 Fax: 051-669-4669

(c) 2020, Korean Society of Environmental Engineers 


\section{연구논문}

\section{생물활성탄 공정에서 과산화수소와 인산염 투입이 바이오폴리머 생성 및 손실 수두 변화에 미치는 영향}

손희종 ${ }^{+} \cdot$ 정은영 ${ }^{\oplus}$ 김희영 ${ }^{\circledR} \cdot$ 김상구 $^{\odot}$

부산광역시 상수도사업본부 수질연구소

목적 : 인산염과 과산화수소 투입 유무에 따른 생물활성탄(biological activated carbon, BAC) 공정 유출수 중의 biopolymers 농도 및 $\mathrm{BAC}$ 공정 여층의 손실 수두 변화를 평가하여 보다 효율적인 $\mathrm{BAC}$ 공정의 운전 방안을 제시하고자 하였다.

방법: $\mathrm{BAC}$ 공정 시스템은 내경 $20 \mathrm{~cm}$, 높이 $250 \mathrm{~cm}$ 의 아크릴 컬럼 4 개를 사용하여 공탑 체류시간은 20 분, 역세 척은 주 1 회 실시하였다. 실험기간 동안 후오존은 $1 \mathrm{mg} \cdot \mathrm{O}_{3} / \mathrm{mg} \cdot \mathrm{DOC}$ 로 고정하여 투입하였다. 4 개의 $\mathrm{BAC}$ 컬럼들 은 기존 $\mathrm{BAC}$ (control-BAC), 인을 투입한 강화 $\mathrm{BAC}\left(\mathrm{PO}_{4}-\mathrm{P}+\mathrm{BAC}\right)$, 과산화수소를 투입한 강화 $\mathrm{BAC}\left(\mathrm{H}_{2} \mathrm{O}_{2}+\mathrm{BAC}\right)$ 및 인과 과산화수소를 함께 투입한 강화 $\mathrm{BAC}\left(\mathrm{PO}_{4}-\mathrm{P}+\mathrm{H}_{2} \mathrm{O}_{2}+\mathrm{BAC}\right)$ 이다. $\mathrm{PO}_{4}-\mathrm{P}$ 를 투입한 강화 $\mathrm{BAC}$ 의 경우 유입수 에 $0.010 \mathrm{mg} / \mathrm{L}$ 의 농도로 $\mathrm{PO}_{4}-\mathrm{P}$ 를 추가로 보충하였으며, $\mathrm{H}_{2} \mathrm{O}_{2}$ 를 투입한 $\mathrm{BAC}$ 에서는 $\mathrm{H}_{2} \mathrm{O}_{2}$ 를 유입수에 $1 \mathrm{mg} / \mathrm{L}$ 의 농 도로 투입하였다.

결과 및 토의: 수온의 변화에 따른 control-BAC에서의 평균 손실 수두는 $4.4 \mathrm{~cm}\left(25 \sim 28^{\circ} \mathrm{C}\right) \sim 7.7 \mathrm{~cm}\left(8 \sim 12^{\circ} \mathrm{C}\right)$ 였으며, $\mathrm{PO}_{4}-\mathrm{P}+\mathrm{BAC}, \mathrm{H}_{2} \mathrm{O}_{2}+\mathrm{BAC}$ 및 $\mathrm{PO}_{4}-\mathrm{P}+\mathrm{H}_{2} \mathrm{O}_{2}+\mathrm{BAC}$ 에서는 각각 $3.9 \mathrm{~cm} \sim 5.8 \mathrm{~cm}, 2.5 \mathrm{~cm} \sim 3.5 \mathrm{~cm}$ 및 $2.6 \mathrm{~cm} 3.5 \mathrm{~cm}$ 로 나 타났다. 인과 과산화수소의 투입으로 손실수두가 저감되었다. 수온이 낮은 시기에 control-BAC에서는 biopolymers (BP) 성분의 유출농도가 유입농도보다 높게 나타나 생물막에서 다량의 EPS (extracellular polymeric substances)가 생성되어 유출되는 것으로 나타났다. Control-BAC에 비하여 $\mathrm{PO}_{4}-\mathrm{P}+\mathrm{BAC}, \mathrm{H}_{2} \mathrm{O}_{2}+\mathrm{BAC}$ 및 $\mathrm{PO}_{4}-\mathrm{P}+\mathrm{H}_{2} \mathrm{O}_{2}+\mathrm{BAC}$ 에서는 수온 $8 \sim 12{ }^{\circ} \mathrm{C}$ 기간에 $\mathrm{BP}$ 의 잔존비 $\left(\mathrm{C}_{\mathrm{out}} / \mathrm{C}_{\mathrm{in}}\right)$ 가 $36 \sim 57 \%$ 정도 낮았다. $\mathrm{BP}$ 잔존비의 경우, 수온이 낮을수록 높게 나타 났고, 수온이 상승할수록 점진적으로 감소하였다. 이러한 결과는 control-BAC와 강화 $\mathrm{BAC}$ 공정들에서의 손실 수 두 변화결과와 매우 유사하였고, $\mathrm{BP}$ 농도 잔존비와 손실 수두는 매우 높은 상관관계 $\left(r^{2}=0.82 \sim 0.87\right)$ 를 나타내었다. 운전기간 동안의 생물막 안정도 평가를 위해 $\mathrm{BAC}$ 처리수 중의 평균 총 박테리아 개체수(total cell counts, TCC)를 조사한 결과, control- $\mathrm{BAC}, \mathrm{PO}_{4}-\mathrm{P}+\mathrm{BAC}, \mathrm{H}_{2} \mathrm{O}_{2}+\mathrm{BAC}$ 및 $\mathrm{PO}_{4}-\mathrm{P}+\mathrm{H}_{2} \mathrm{O}_{2}+\mathrm{BAC}$ 공정에서 각각 $46.8 \times 10^{6}$ cells, $30.3 \times 10^{6}$ cells, $21.8 \times 10^{6}$ cells 및 $18.8 \times 10^{6}$ cells로 나타나 control-BAC에 비해 강화 $\mathrm{BAC}$ 공정들 유출수에서 $35 \sim 60 \%$ 정도 낮게 나타났다. 또한, TCC 중에서 활성 박테리아 개체수(live cell count, LCC) 비(LCC/TCC)의 경우도 control-BAC 의 0.53에 비해 강화 BAC 공정들에서는 0.84 0.89 범위로 나타나 강화 $\mathrm{BAC}$ 공정들의 부착 생물막의 안정도가 높은 것으로 조사되었다.

결론 : 운전기간 동안 기존 $\mathrm{BAC}$ (control-BAC) 공정에 비하여 인과 과산화수소를 투입한 강화 $\mathrm{BAC}$ 공정들에서 손 실 수두 저감효과가 뚜렷하게 나타났다. 특히, 인을 투입한 경우보다 과산화수소를 투입한 경우에 손실 수두 저감 효과가 높았다. 저수온기에 강화 BAC 공정들에 비하여 control-BAC에서의 급격한 손실 수두 증가는 생물막에서의 다량의 EPS 생성으로 인한 결과이며, 인이나 과산화수소 투입으로 부착 생물막의 안정도(stability) 향상 및 EPS 생 성량을 저감시켜 손실 수두를 감소시킬 수 있었다.

주제어 : 생물활성탄, 과산화수소, 인, 손실 수두, 수온, 바이오폴리머

\section{1. 서론}

각종 산업기술의 발달로 인하여 다양한 합성물질들이 개 발되어 사용되고, 이들의 사용량도 급증하고 있어 상수원수
뿐만 아니라 수돗물에서도 합성 오염물질들이 검출된다는 많은 연구결과들이 보고되고 있다. ${ }^{1-5)}$ 이러한 합성 오염물질 들이 상수원에 유입되어 수돗물을 생산하는 정수장으로 유 입될 경우, 응집-침전-모래여과와 같은 기존 재래식 정수처 
Table 1. Characteristics of post-ozonated water from Feb. to Aug. 2020.

\begin{tabular}{cccccc} 
& $\mathrm{pH}$ & $\mathrm{DOC}$ & $\mathrm{BDOC}$ & $\mathrm{PO}_{4}-\mathrm{P}$ & Temp. \\
& $(-)$ & $(\mathrm{mg} / \mathrm{L})$ & $(\mathrm{mg} / \mathrm{L})$ & $(\mathrm{mg} / \mathrm{L})$ & $\left({ }^{\circ} \mathrm{C}\right)$ \\
Influent water & $6.9 \sim 7.8$ & $2.11 \sim 3.01$ & $0.30 \sim 0.83$ & $\mathrm{ND} 0.013$ & $(0.005)^{\mathrm{a}}$ \\
\hline
\end{tabular}

${ }^{a}$ average concentration

리 공법으로는 제거하기가 매우 어렵다. ${ }^{5)}$ 따라서 국내에서 도 1990년대부터 고도 정수처리 공정의 일종인 오존/생물활 성탄 공정이 전국의 대규모 정수장에 도입되어 운영 중에 있다.

일반적으로 생물활성탄(biological activated carbon, BAC) 공정은 활성탄 표면과 세공에 박테리아들이 자연적으로 부 착되어 형성된 생물막에 의해 수중의 오염물질이 분해·제 거되는 원리이며, 다양한 유기성 오염물질들에 대해 우수한 제거능을 나타낸다. ${ }^{6)} \mathrm{BAC}$ 공정의 운전효율에 영향을 미치 는 인자들로는 활성탄의 재질, 여과 속도, 공탑 체류시간 (empty bed contact time, EBCT), 역세척, 수온, 제한 영양물 질 등 다양하다. ${ }^{6}$ 특히, 역세척의 경우는 처리수의 수질과 수량에 영향을 미치기 때문에 매우 중요한 운전인자로 평가 되고 있다. ${ }^{7,8)} \mathrm{BAC}$ 공정의 역세척 주기는 유입수 성상에 많 이 좌우되고 ${ }^{8)}$, 역세척 주기나 조건에 문제가 있을 경우에는 $\mathrm{BAC}$ 여과지의 손실수두가 증가하며, $\mathrm{BAC}$ 처리수 중으로 입자상 물질의 유출농도가 증가한다. ${ }^{9} \mathrm{BAC}$ 공정을 운전 중 인 국내 정수장의 경우, 하절기에는 3 5일 주기로 역세척을 하며, 동절기에는 주 1 회 정도로 수행하고 있다. ${ }^{8)}$

최근에는 $\mathrm{BAC}$ 공정의 유입수에 영양염 $(\mathrm{N}, \mathrm{P})$ 과 과산화수 소를 투입하여 $\mathrm{BAC}$ 공정 효율을 증대시키는 강화 $\mathrm{BAC}$ 공 정에 대한 연구가 많이 수행되고 있다. ${ }^{10-12)} \mathrm{BAC}$ 공정에 투 입되는 영양염과 과산화수소는 $\mathrm{BAC}$ 부착 생물막의 활성을 촉진시키고 ${ }^{12)}, \mathrm{BAC}$ 부착 생물막에서 분비되는 다당류와 폴 리머들로 구성된 접착성의 세포외 고분자물질(extracellular polymeric substances, EPS)의 생성을 억제하여 생물막에 의해 유발되는 손실 수두를 감소시키는 역할을 한다. ${ }^{10,11)}$ $\mathrm{BAC}$ 여과지 유입수 중에 인(P) 농도가 충분하지 않은 경우, $\mathrm{BAC}$ 부착 생물막의 구조 및 형태 변형이 유발되어 오염물질 제거능 감소뿐만 아니라 손실수두도 증가한다. ${ }^{13)}$ 박테리아의 증식 및 생장에 필요한 일반적인 $\mathrm{C}(\mathrm{BDOC}): \mathrm{N}\left(\mathrm{NH}_{4}-\mathrm{N}\right): \mathrm{P}$ $\left(\mathrm{PO}_{4}-\mathrm{P}\right)$ 는 $100(1 \mathrm{mg} / \mathrm{L}): 10(0.117 \mathrm{mg} / \mathrm{L}): 1(0.026 \mathrm{mg} / \mathrm{L})$ 로 보고되고 있다. ${ }^{14)}$ 과산화수소는 생물막에 용존산소 공급 역할뿐만 아니라 유기물 산화능을 증대시키는 과산화 효소 발현을 촉진한다. ${ }^{15)}$ 또한, 저농도 $(1 \mathrm{mg} / \mathrm{L})$ 의 과산화수소 투 입은 $\mathrm{BAC}$ 부착 생물막에 존재하는 활성 생체량의 생물학 적 활성은 유지시키면서 비활성 생체량은 산화·제거시키는 것으로 보고되고 있다. ${ }^{16,17)}$

본 연구에서는 낙동강 원수를 정수처리하는 파일럿 플랜 트를 이용하여 인과 과산화수소 투입 유무에 따른 BAC 공
정에서의 손실 수두 변화 및 처리수중의 biopolymer 성분 변화를 평가하여 오존/생물활성탄 공정의 효율적인 운영가 능성을 평가하였다.

\section{2. 실험재료 및 방법}

\section{1. 실험재료}

\subsubsection{BAC 공정 유입수}

파일럿 플랜트의 후오존 처리수를 $\mathrm{BAC}$ 공정의 유입수로 사용하였다. 파일럿 플랜트는 300 톤/일 처리규모로 낙동강 하류 원수를 취수하여 전오존-응집/침전-급속 모래여과-후 오존-생물활성탄 공정으로 구성되어져 있다. 후오존 투입농 도는 실험기간 동안 $1 \mathrm{mg} \cdot \mathrm{O}_{3} / \mathrm{mg} \cdot \mathrm{DOC}$ 로 고정하여 운전하 였다. 후오존 처리 후에는 후오존 저류조를 설치하여 잔류 오존을 완전히 소모시킨 후 $\mathrm{BAC}$ 공정으로 후오존 처리수 를 공급하였다. Table 1에는 실험기간 동안의 후오존 처리 수 성상을 나타내었다.

\subsubsection{BAC 컬럼 시스템 및 운전}

실험에 사용된 생물활성탄(BAC)은 정수장의 오존/BAC 공 정에서 2 년간 사용한 활성탄을 채집 후 내경 $20 \mathrm{~cm}$, 높이 250 $\mathrm{cm}$ 의 아크릴 컬럼 4 개에 층고 $100 \mathrm{~cm}$ 가 되도록 충진하여 1 년 정도 실험 조건에 맞게 인 $\left(\mathrm{PO}_{4}-\mathrm{P}\right)$ 과 과산화수소 $\left(\mathrm{H}_{2} \mathrm{O}_{2}\right)$ 를 투입하여 운영한 후 본 실험을 수행하였다. 각각의 아크릴 컬럼들에는 손실 수두 측정을 위한 줄자(measuring tape)를 설치하여 손실 수두 변화를 측정하였다.

$\mathrm{BAC}$ 컬럼 유입수는 후오존 처리수조에서 잔류오존이 완 전히 소모된 후에 펌프로 각각의 $\mathrm{BAC}$ 컬럼들 상부로 공급 하였다. 공탑 체류시간(empty bed contact time, EBCT)은 20 분으로 고정하여 운전하였으며, 역세척은 공세 3 분, 수세 10 분 의 조건으로 주 1 회 실시하였다.

4 개의 $\mathrm{BAC}$ 컬럼들은 인 $\left(\mathrm{PO}_{4}-\mathrm{P}\right)$ 과 과산화수소 $\left(\mathrm{H}_{2} \mathrm{O}_{2}\right)$ 를 투입하지 않는 $\mathrm{BAC}$ 컬럼(control-BAC), $\mathrm{H}_{2} \mathrm{O}_{2}$ 를 투입 하는 $\mathrm{BAC}$ 컬럼 $\left(\mathrm{H}_{2} \mathrm{O}_{2}+\mathrm{BAC}\right), \mathrm{PO}_{4}-\mathrm{P}$ 를 투입하는 $\mathrm{BAC}$ 컬럼 $\left(\mathrm{PO}_{4}-\mathrm{P}+\mathrm{BAC}\right)$ 및 $\mathrm{PO}_{4}-\mathrm{P}$ 와 $\mathrm{H}_{2} \mathrm{O}_{2}$ 를 함께 투입하는 $\mathrm{BAC}$ 컬 럼 $\left(\mathrm{PO}_{4}-\mathrm{P}+\mathrm{H}_{2} \mathrm{O}_{2}+\mathrm{BAC}\right)$ 이다. 4 개의 $\mathrm{BAC}$ 컬럼들은 1 년 정도 각각의 강화 운전조건 $\left(\mathrm{PO}_{4}-\mathrm{P}\right.$ 와 $\mathrm{H}_{2} \mathrm{O}_{2}$ 투입)에 맞게 $\mathrm{PO}_{4}-\mathrm{P}$ 와 $\mathrm{H}_{2} \mathrm{O}_{2}$ 를 투입하였으며, 1 년간의 운전으로 각각의 $\mathrm{BAC}$ 컬럼 들 내의 생물막이 정상상태에 도달한 이후에 본 연구를 수 행하였다. 

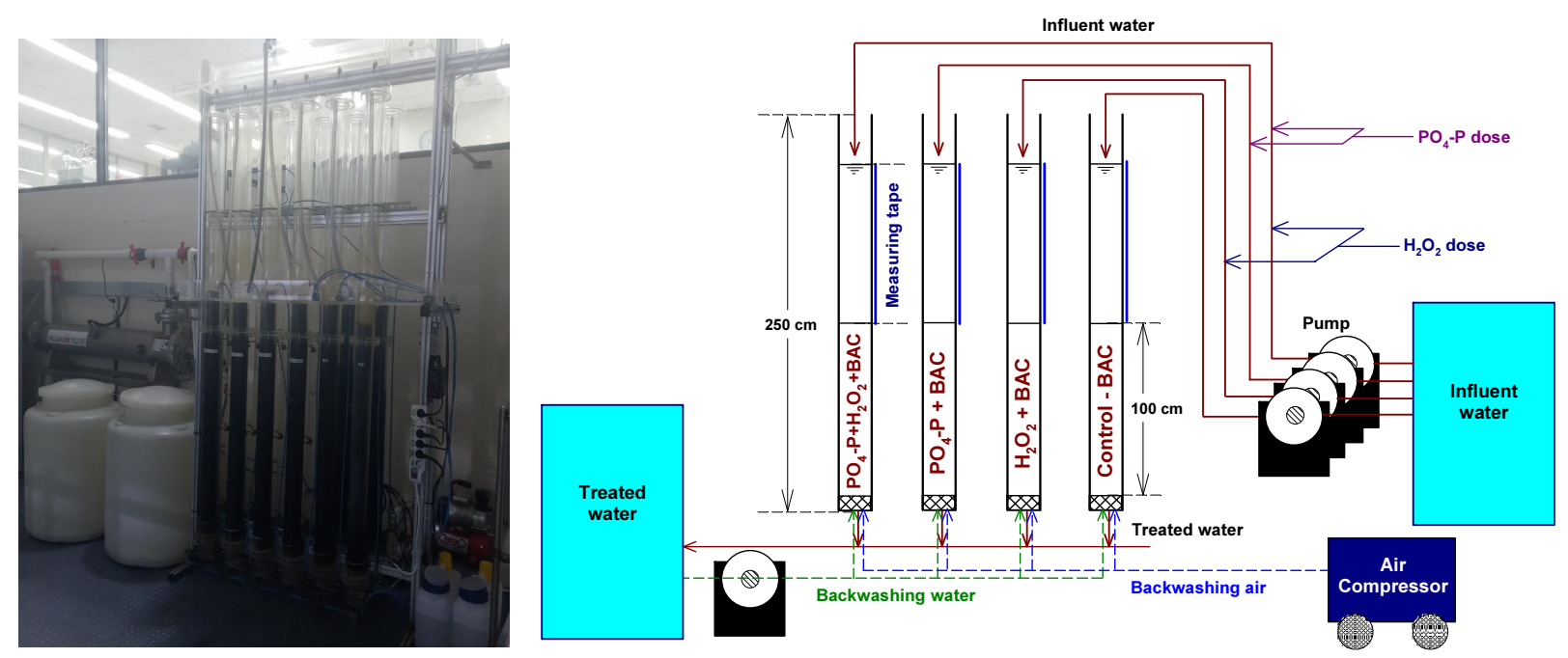

Fig. 1. Photograph and schematic diagram of BAC column system.

Table 2. Biofilm characteristics under steady state according to enhancement conditions of BAC process (Feb. 2020) ( $n=3)$.

\begin{tabular}{|c|c|c|c|c|}
\hline \multirow{2}{*}{ BAC processes } & \multicolumn{2}{|l|}{ Conventional-BAC } & \multicolumn{2}{|c|}{ Enhanced-BAC } \\
\hline & Control-BAC & $\mathrm{PO}_{4}-\mathrm{P}+\mathrm{BAC}$ & $\mathrm{H}_{2} \mathrm{O}_{2}+\mathrm{BAC}$ & $\mathrm{PO}_{4}-\mathrm{P}+\mathrm{H}_{2} \mathrm{O}_{2}+\mathrm{BAC}$ \\
\hline $\begin{array}{c}\text { Biomass } \\
(\mu \mathrm{g} \cdot \mathrm{ATP} / \mathrm{g} \cdot \mathrm{GAC})\end{array}$ & $2.83 \pm 0.21$ & $3.25 \pm 0.17$ & $3.02 \pm 0.19$ & $3.32 \pm 0.27$ \\
\hline $\begin{array}{c}\text { Activity } \\
(\mathrm{mg} \cdot \mathrm{C} / \mathrm{g} \cdot \mathrm{hr})\end{array}$ & $2.42 \pm 0.22$ & $2.93 \pm 0.24$ & $3.07 \pm 0.16$ & $3.12 \pm 0.31$ \\
\hline
\end{tabular}

Fig. 1 의 개략도에서 볼 수 있듯이 각각의 $\mathrm{BAC}$ 컬럼으로 이송되는 후오존 처리수 공급라인에 $\mathrm{PO}_{4}-\mathrm{P}$ 와 $\mathrm{H}_{2} \mathrm{O}_{2}$ 공급용 정밀유량 펌프(Masterflex ${ }^{\circledR} \mathrm{L} / \mathrm{S}^{\circledR}$, Cole-Parmer, USA)를 설 치하여 각각의 $\mathrm{BAC}$ 컬럼들의 운전조건에 알맞게 $\mathrm{PO}_{4}-\mathrm{P}$ 와 $\mathrm{H}_{2} \mathrm{O}_{2}$ 를 투입하였다.

$\mathrm{PO}_{4}-\mathrm{P}$ 가 공급되는 두 개의 강화 $\mathrm{BAC}$ 컬럼들 $\left(\mathrm{PO}_{4}-\mathrm{P}+\mathrm{BAC}\right.$, $\mathrm{PO}_{4}-\mathrm{P}+\mathrm{H}_{2} \mathrm{O}_{2}+\mathrm{BAC}$ )에 대해서는 유입수에 잔존하는 $\mathrm{PO}_{4}-\mathrm{P}$ 농도에 더하여 추가적으로 $0.010 \mathrm{mg} / \mathrm{L}$ 의 $\mathrm{PO}_{4}-\mathrm{P}$ 가 더 공급 되도록 $\mathrm{PO}_{4} \mathrm{P}$ 를 투입하였다. ${ }^{12)} \mathrm{Table} 1$ 에서 볼 수 있듯이 실 험기간 동안 후오존 처리수 중의 $\mathrm{PO}_{4}-\mathrm{P}$ 농도는 평균 0.005 $\mathrm{mg} / \mathrm{L}$ 였다.

$\mathrm{H}_{2} \mathrm{O}_{2}$ 가 공급되는 두 개의 강화 $\mathrm{BAC}$ 컬럼들 $\left(\mathrm{H}_{2} \mathrm{O}_{2}+\mathrm{BAC}\right.$, $\mathrm{PO}_{4}-\mathrm{P}+\mathrm{H}_{2} \mathrm{O}_{2}+\mathrm{BAC}$ )에는 $\mathrm{BAC}$ 컬럼들의 유입 $\mathrm{H}_{2} \mathrm{O}_{2}$ 농도가 $1 \mathrm{mg} / \mathrm{L}$ 가 되도록 운전하였다. ${ }^{12)} \mathrm{PO}_{4}-\mathrm{P}$ 와 $\mathrm{H}_{2} \mathrm{O}_{2}$ 는 각각 $85 \%$ 인산(Sigma-aldrich, USA)과 $30 \%$ 과산화수소(Sigma-aldrich, USA)를 희석하여 사용하였다.

1 년간의 운전으로 기존 $\mathrm{BAC}$ 공정(control-BAC)과 강화 $\mathrm{BAC}$ 공정(enhanced-BAC)들의 활성탄 부착 생물막의 생체 량과 활성도가 정상 상태에 도달한 이후에 생물막 특성을 분석한 결과를 Table 2에 나타내었다. 기존 $\mathrm{BAC}$ 공정에 비 하여 강화 $\mathrm{BAC}$ 공정들의 생체량과 활성도가 각각 7 17\% 및 21 29\% 정도 높게 나타났다.

\section{2. 실험방법}

\subsubsection{BAC 부착 박테리아 생체량 및 활성도}

부착 박테리아의 생체량(ATP 농도)의 측정은 활성탄 습중 량 $200 \mathrm{mg}$ 을 채집하여 Velten 등이 제시한 방법 ${ }^{18}$ 으로 전처 리하여 luminometer (Victor3, PerkinElmer, USA)를 이용하 여 분석하였다.

부착 박테리아의 활성도는 ${ }^{3} \mathrm{H}$-thymidine이 박테리아의 DNA에 흡수되는 양으로 평가하는 방법을 이용하였으며 ${ }^{19}$, 실험은 활성탄 습중량 $1 \mathrm{~g}$ 을 전처리하여 liquid scintillation analyzer (PerkinElmer, Quantulus 1220, USA)로 분석하였다.

\subsection{2. 총 박테리아 개체수 분석 ${ }^{12)}$}

$\mathrm{BAC}$ 컬럼 처리수 중의 총 박테리아 개체수(total cell count, TCC)는 flow cytometer (CytoFLEX, Beckman Coulter, USA) 를 사용하여 분석하였다. GF/C 여지(Whatman, USA)로 여과한 시료 $300 \mu \mathrm{L}$ 에 SYBR 염색약(SYBR ${ }^{\circledR}$ Gold nucleic acid gel stain, Invitrogen, USA) $10 \mu \mathrm{L}$ 와 $50 \mu \mathrm{g} / \mathrm{mL}$ 농도로 조제한 PI 염색약(propidium iodide, Invitrogen, USA) $10 \mu \mathrm{L}$ 를 첨가 후 혼화시켜 10 분간 정치시킨 후 flow cytometer로 분석하였다.

\subsubsection{Biopolymer 분석}

수중의 biopolymer 농도 분석에는 LC-OCD (Model 8, DOC-Labor, Germany) 시스템을 이용하였다. Size exclusion 

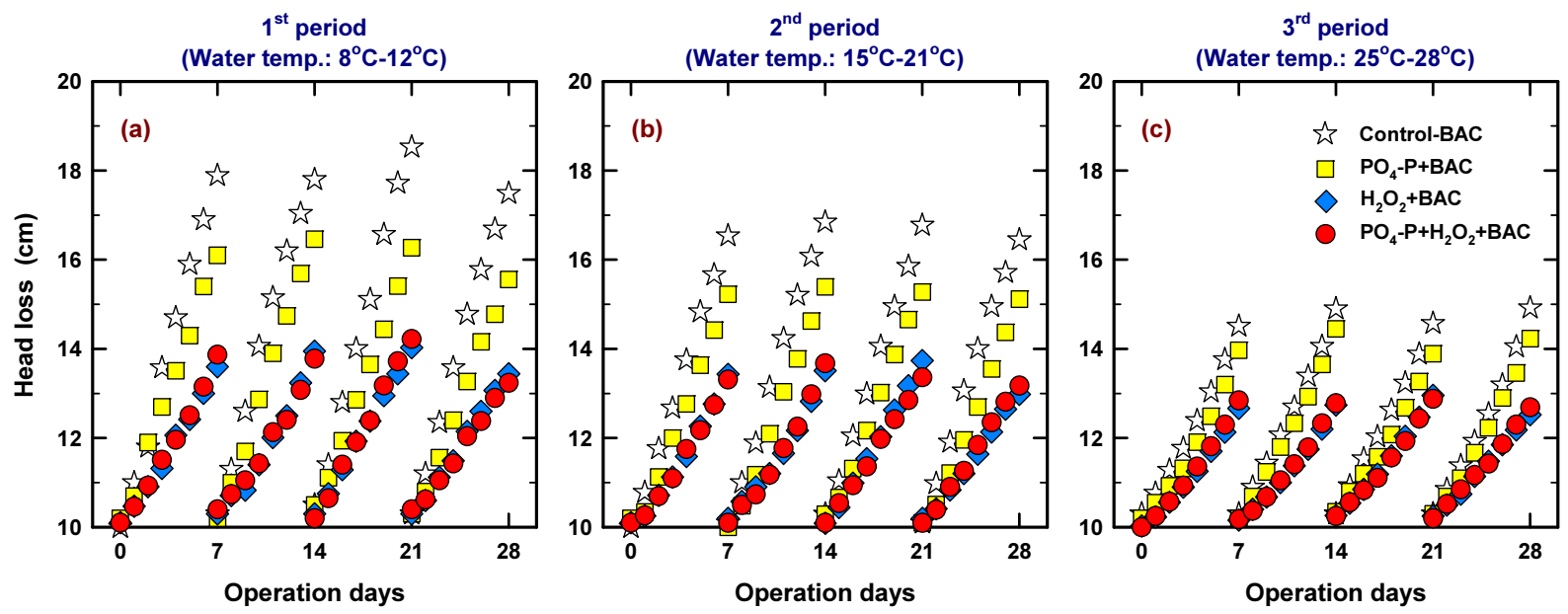

Fig. 2. Changes of head loss during $1^{\text {st }} 3^{\text {rd }}$ pilot test period.

chromatography (SEC) 컬럼(Toyopearl TSK HW-50S, $250 \times$ $20 \mathrm{~mm}$ ) 및 ultraviolet detector (UVD), organic carbon detector (OCD)가 장착되어 있어 수중에 혼재되어 있는 용존 유기물질 을 biopolymer, humic substances, building block, low molecular weight (LMW) acids 및 LMW neutrals로 분류하 여 정성-정량이 가능하다. ${ }^{20)}$ 이동상으로는 phosphate buffer 를 사용하였고, 산화제 $(4 \mathrm{~mL}$ phosphoric acid (Fluka) $+0.5 \mathrm{~g}$ potassium peroxodisulfate (Fluka) to $1 \mathrm{~L} \mathrm{DW}$ )를 주입하여 Gräntzel thin film reactor에서 유기물질을 완전 산화시키며, 정량한계는 $0.01 \mathrm{mg} \cdot \mathrm{C} / \mathrm{L}$ 이다. ${ }^{20)}$

\section{3. 결과 및 고찰}

\section{1. 강화 조건에 따른 BAC 공정별 손실 수두 변화}

강화 조건에 따른 $\mathrm{BAC}$ 여과지별 손실 수두 변화에 대한 평가결과를 Fig. 2에 나타내었다. 유입수의 수온 변화에 따라 수온 $8 \sim 12^{\circ} \mathrm{C}$ 기간(Fig. 2(a)), 수온 $15 \sim 21^{\circ} \mathrm{C}$ 기간(Fig. 2(b)) 및 수온 $25 \sim 28^{\circ} \mathrm{C}$ 기간(Fig. 2(c))과 같이 3 개의 기간으로 나 누어 평가하였다. 전체적으로 수온이 상승할수록 손실 수두 가 감소하였으며, 기존 $\mathrm{BAC}$ 공정(control-BAC)에 비하여 강 화 $\mathrm{BAC}$ 공정을 적용한 경우에 손실 수두 증가가 작게 나타 났다.

Fig. 2(a)에 나타낸 수온 $8 \sim 12^{\circ} \mathrm{C}$ 기간( $1^{\text {st }}$ period)의 경우, control-BAC의 역세척 직전까지 평균 손실 수두 증가량은 $7.7 \mathrm{~cm}$ 였으며, 인을 투입한 $\mathrm{PO}_{4}-\mathrm{P}+\mathrm{BAC}$ 는 $5.8 \mathrm{~cm}$, 과산화 수소를 투입한 $\mathrm{H}_{2} \mathrm{O}_{2}+\mathrm{BAC}$ 와 인과 과산화수소를 동시에 투 입한 $\mathrm{PO}_{4}-\mathrm{P}+\mathrm{H}_{2} \mathrm{O}_{2}+\mathrm{BAC}$ 의 경우는 각각 $3.1 \mathrm{~cm}$ 및 $2.8 \mathrm{~cm}$ 로 나타났다.

수온 $15 \sim 21^{\circ} \mathrm{C}$ 기간( $2^{\text {nd }}$ period $)$ 의 경우에는 control-BAC의 평 균 손실 수두 증가량은 $6.5 \mathrm{~cm}$ 였으며, $\mathrm{PO}_{4}-\mathrm{P}+\mathrm{BAC}, \mathrm{H}_{2} \mathrm{O}_{2}+\mathrm{BAC}$ 및 $\mathrm{PO}_{4}-\mathrm{P}+\mathrm{H}_{2} \mathrm{O}_{2}+\mathrm{BAC}$ 공정에서의 평균 손실 수두 증가량은 각각 $5.1 \mathrm{~cm}, 3.3 \mathrm{~cm}$ 및 $3.3 \mathrm{~cm}$ 로 나타났다. 또한, 수온 $25 ~ 28^{\circ} \mathrm{C}$
기간 $\left(3^{\text {rd }}\right.$ period $)$ 의 경우, control-BAC의 평균 손실 수두 증가량 은 $4.4 \mathrm{~cm}$ 였고, $\mathrm{PO}_{4}-\mathrm{P}+\mathrm{BAC}, \mathrm{H}_{2} \mathrm{O}_{2}+\mathrm{BAC}$ 및 $\mathrm{PO}_{4}-\mathrm{P}+\mathrm{H}_{2} \mathrm{O}_{2}+\mathrm{BAC}$ 공정에서의 평균 손실 수두 증가량은 각각 $3.9 \mathrm{~cm}, 2.5 \mathrm{~cm}$ 및 $2.6 \mathrm{~cm}$ 로 나타났다.

Fig.2의 수온 변화와 강화 조건에 따른 $\mathrm{BAC}$ 여과지에서 의 증가된 손실 수두량을 실험기간별로 평균하여 Fig.3에 나타내었다. 수온이 상승할수록 기존 $\mathrm{BAC}$ (control)의 경우 증가된 손실 수두가 $7.7 \mathrm{~cm}\left(8 \sim 12^{\circ} \mathrm{C}\right)$ 에서 $6.5 \mathrm{~cm}\left(15 \sim 21^{\circ} \mathrm{C}\right)$ 와 $4.4 \mathrm{~cm}\left(25 \sim 28^{\circ} \mathrm{C}\right)$ 로 감소하여 수온 상승에 따른 손실 수 두 감소율은 각각 $15.6 \%$ 와 $42.9 \%$ 로 나타났다. $\mathrm{PO}_{4} \mathrm{P}+\mathrm{BAC}$ 의 경우는 수온 $8 \sim 12^{\circ} \mathrm{C}$ 기간에는 증가된 손실 수두가 평균 $5.8 \mathrm{~cm}$ 였으나 수온이 $15 \sim 21^{\circ} \mathrm{C}$ 와 $25 \sim 28^{\circ} \mathrm{C}$ 로 상승할수록 수 온 상승에 따른 손실 수두 감소율은 각각 $12.1 \%$ 와 $32.8 \%$ 로 나타났다. 또한, $\mathrm{H}_{2} \mathrm{O}_{2}+\mathrm{BAC}$ 와 $\mathrm{PO}_{4}-\mathrm{P}+\mathrm{H}_{2} \mathrm{O}_{2}+\mathrm{BAC}$ 의 경우, 수온 $8 \sim 12{ }^{\circ} \mathrm{C}$ 기간에 비해 수온 $15 \sim 21^{\circ} \mathrm{C}$ 와 $25 \sim 28^{\circ} \mathrm{C}$ 기간에 서는 손실 수두 감소율이 각각 $5.7 \%$ 와 $28.6 \%$ 및 $5.7 \%$ 와 $25.7 \%$ 로 나타나 $\mathrm{H}_{2} \mathrm{O}_{2}+\mathrm{BAC}$ 와 $\mathrm{PO}_{4}-\mathrm{P}+\mathrm{H}_{2} \mathrm{O}_{2}+\mathrm{BAC}$ 에서는 손 실 수두 감소율이 거의 유사하게 나타났다. 일반적으로 수온 이 상승하면 여과공정에서의 손실 수두는 감소하며, $\mathrm{BAC}$ 공 정에서는 동절기에 비하여 하절기에 수온 상승으로 인하여 손실 수두가 $20 \sim 30 \%$ 정도 감소하는 것으로 보고되어 있다. ${ }^{8)}$

수온 $8 \sim 12^{\circ} \mathrm{C}$ 기간에는 기존 $\mathrm{BAC}$ 여과지(control)에 비하 여 강화 공정을 적용한 $\mathrm{BAC}$ 여과지들에서 손실 수두가 현 저히 감소되었으며, 기존 $\mathrm{BAC}$ 에 비하여 $\mathrm{PO}_{4}-\mathrm{P}+\mathrm{BAC}$ 에서의 손실 수두 감소율은 $25 \%$ 정도로 나타난 반면 과산화수소를 투입한 $\mathrm{H}_{2} \mathrm{O}_{2}+\mathrm{BAC}$ 와 $\mathrm{PO}_{4}-\mathrm{P}+\mathrm{H}_{2} \mathrm{O}_{2}+\mathrm{BAC}$ 에서의 손실 수두 감소율은 모두 $55 \%$ 로 나타나 과산화수소를 투입한 $\mathrm{BAC}$ 여과지에서의 손실 수두 개선 효과가 인 $\left(\mathrm{PO}_{4}-\mathrm{P}\right)$ 을 투입한 경우보다 높게 나타났다. 또한, 수온이 상승한 $15 ~ 21{ }^{\circ} \mathrm{C}$ 와 $25 \sim 28^{\circ} \mathrm{C}$ 기간의 결과에서도 기존 $\mathrm{BAC}$ 공정에 비하여 $\mathrm{PO}_{4}-\mathrm{P}$, $\mathrm{H}_{2} \mathrm{O}_{2}$ 및 $\mathrm{PO}_{4}-\mathrm{P}+\mathrm{H}_{2} \mathrm{O}_{2}$ 를 투입한 경우가 각각 $22 \% \sim 49 \%$ 및 $11 \% \sim 3 \%$ 정도 손실 수두가 감소하였으며, $\mathrm{PO}_{4}-\mathrm{P}$ 을 강화시 


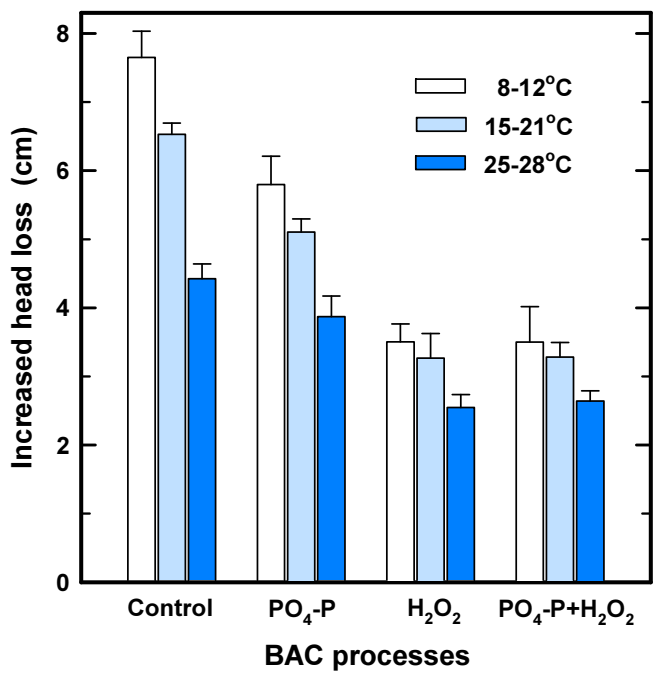

Fig. 3. Head loss change according to water temperature change $(n=4)$.

킨 경우보다 $\mathrm{H}_{2} \mathrm{O}_{2}$ 강화 조건에서 손실 수두 개선효과가 높 게 나타났다.

$\mathrm{BAC}$ 공정은 응집/침전/모래여과 공정의 후단에 위치하기 때문에 손실 수두를 유발하는 입자상 물질들이 거의 제거된 유입수가 공급되므로 $\mathrm{BAC}$ 공정과 같은 생물여과 공정에서 손실 수두를 유발하는 주요 원인은 여재에 부착된 생물막에 서 분비되는 점착성의 고분자 유기물질인 $\mathrm{EPS}$ 에 기인된 것 으로 알려져 있다. ${ }^{10,11)}$ 강화 목적으로 투입되는 인과 과산화 수소는 $\mathrm{BAC}$ 부착 생물막의 활성을 촉진시켜 생물막에서 분비되는 점착성의 고분자 유기물질인 EPS의 생성을 억제 함으로서 생물막에 의해 유발되는 손실 수두를 큰 폭으로 감소시켰다.

생물막에서 분비되는 $\mathrm{EPS}$ 는 유입수의 급격한 $\mathrm{pH}$ 변화, 독성물질 유입 및 역세척시 전단력 등과 같은 $\mathrm{BAC}$ 표면에 형성된 생물막내의 박테리아 군집에 스트레스를 유발하는 여러 상황에서 이들을 보호하는 역할을 한다. ${ }^{21-23)}$ 그러나, 과도한 EPS 생성은 여층 내의 빈 공간을 줄임과 동시에 서 로 이웃한 여재들을 서로 접착시켜 수류 흐름과 생물막으로 의 영양분 공급을 방해하여 여층 오염을 촉진함으로써 여층 의 막힘을 유발한다. ${ }^{22,24)}$ 저농도 $(1 \mathrm{mg} / \mathrm{L}$ 이하)로 투입된 과 산화수소는 생물막 내의 활성 바이오매스의 생물학적 활성 을 유지시키면서 비활성 바이오매스와 EPS를 효과적으로 산화·제거시킨다. ${ }^{16,25)}$ 과산화수소에 의한 $\mathrm{EPS}$ 의 제거 메카 니즘은 과산화수소에 의한 폴리머 사슬 절단으로 $\mathrm{EPS}$ 를 구 성하고 있는 중합체 골격 파괴로 인하여 EPS가 제거된다. ${ }^{25)}$

\section{2. 강화 조건에 따른 $\mathrm{BAC}$ 공정별 처리수 중의 biopolymers 농도 변화}

수온 $8 \sim 12^{\circ} \mathrm{C}$ 기간 중에 기존 $\mathrm{BAC}$ 공정 처리수와 다양한 강화 공정이 적용된 강화 $\mathrm{BAC}$ 공정 처리수들을 $\mathrm{LC}-\mathrm{OCD}$ 로

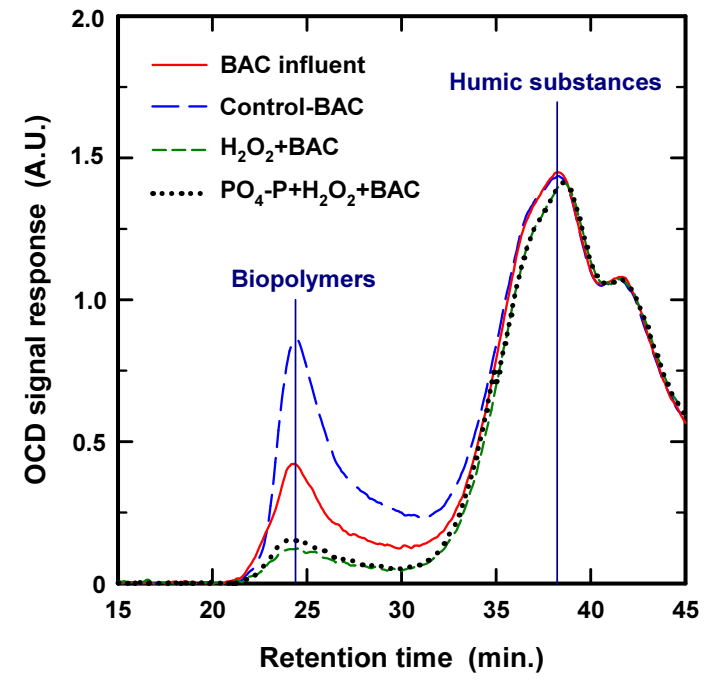

Fig. 4. LC-OCD chromatograms for $B A C$ influent and effluents of BACs (water temp.: $8 \sim 12^{\circ} \mathrm{C}$ ).

분석한 크로마토그램을 Fig.4에 나타내었다. EPS는 생체 고 분자 유기물질로 LC-OCD 크로마토그램에서는 biopolymers (BP)로 머무름 시간(retention time) 20 분 35 분에 걸쳐서 검 출된다. $\mathrm{BAC}$ 유입수에 함유된 $\mathrm{BP}$ 는 원수에 함유된 조류 (algae)의 대사산물이 응집/침전 공정에서 일부 제거되고 후 단 공정으로 유입된 것으로 $\mathrm{BP}$ 는 활성탄 흡착에 의해서는 제거되지 않고, $\mathrm{BAC}$ 와 같은 생물여과 공정에서 생물분해에 의해 제거되는 것으로 알려져 있다. ${ }^{26,27)}$

Fig.4에 나타낸 크로마토그램에서 확인할 수 있듯이 기존 $\mathrm{BAC}$ 공정 처리수(control-BAC)에 함유된 $\mathrm{BP}$ 의 농도가 $\mathrm{BAC}$ 유입수(BAC influent)의 BP 농도보다 높게 나타났다. 7일 운전 후 역세척 직전에 채수하여 분석한 결과로 수온이 낮은 동절기에는 기존 $\mathrm{BAC}$ 공정의 부착 생물막에서는 다량 의 EPS가 생성되었으며, 앞서 서술한 바와 같이 EPS는 생물 막에 스트레스 유발 원인이 작용할 때 생성되며, Fig.4의 경 우는 낮은 수온이 EPS 분비의 주요 원인으로 판단된다.

또한, Fig.4에 나타낸 강화 공정이 적용된 $\mathrm{BAC}$ 처리수들 $\left(\mathrm{H}_{2} \mathrm{O}_{2}+\mathrm{BAC}\right.$ 와 $\left.\mathrm{PO}_{4}-\mathrm{P}+\mathrm{H}_{2} \mathrm{O}_{2}+\mathrm{BAC}\right)$ 의 크로마토그램을 보면 유입수 중의 $\mathrm{BP}$ peak보다 현저히 감소된 $\mathrm{BP}$ peak들을 볼 수 있다. 이는 기존 $\mathrm{BAC}$ 공정에 비해 강화 공정이 적용된 $\mathrm{BAC}$ 공정의 부착 생물막에서는 EPS 생성이 매우 제한적이 고, 낮은 수온에도 불구하고 유입수에 함유된 $\mathrm{BP}$ 가 원활히 생물분해되어 제거됨을 알 수 있다. 이와 같은 결과는 Fig. 3 에 나타낸 동절기 저수온기 $\left(8 \sim 12^{\circ} \mathrm{C}\right)$ 에 기존 $\mathrm{BAC}$ 공정에 서의 높은 손실 수두 발생과 이에 비해 상대적으로 강화 공 정이 적용된 $\mathrm{BAC}$ 공정의 현저히 낮은 손실 수두 발생과 관 계가 있는 것으로 판단된다.

수온 저하와 같은 생물막에 대한 스트레스 요인이 발생하 면 자체의 방어 메카니즘에 의해 생물막에서 EPS 생성이 증가하며 ${ }^{28-30)}$, 생물막의 물리적 구조와 형태가 변형되어 손 


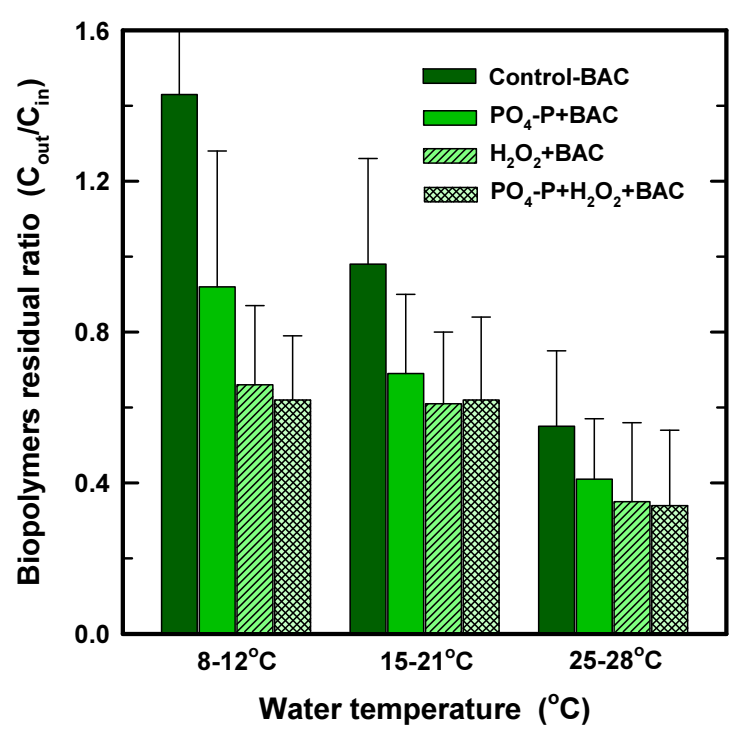

Fig. 5. Biopolymers residual ratio change by enhanced conditions according to water temperature change $(n=4)$.

실수두 증가한다. ${ }^{31}$ 과산화수소의 공급은 생물막에 추가적 인 용존산소 공급원으로 작용할 뿐만 아니라 비활성 바이오 매스와 EPS를 효과적으로 산화·제거시켜 ${ }^{16,25)}$ 생물막의 활 성 유지뿐만 아니라 손실 수두 발생을 억제한다.

수온 변화에 따른 기존 $\mathrm{BAC}$ 공정과 강화 $\mathrm{BAC}$ 공정들의 유입·유출수 중의 $\mathrm{BP}$ 농도 평가를 위해 역세척 직전에 채 수하여 LC-OCD로 분석한 결과를 Fig.5에 나타내었다. Fig. 5 에서 볼 수 있듯이 $\mathrm{BP}$ 의 잔존비 $\left(\mathrm{C}_{\mathrm{ou}} / \mathrm{C}_{\mathrm{in}}\right)$ 의 경우, 수온이 낮을수록 높게 나타났고, 수온이 상승할수록 점진적으로 감 소하였다. 또한, 기존 $\mathrm{BAC}$ 공정과 강화 공정이 적용된 $\mathrm{BAC}$ 공정들 간의 비교에서는 기존 $\mathrm{BAC}$ 공정에 비하여 강 화 $\mathrm{BAC}$ 공정들에서 $\mathrm{BP}$ 잔존비가 현저히 낮게 나타났다. 저 수온기(수온 $8 \sim 12^{\circ} \mathrm{C}$ 기간)에는 $36 ~ 57 \%$ 정도 $\mathrm{BP}$ 의 잔존비 가 낮았으며, 수온 상승에 따라 각각 30 37\%(수온 $15 ~ 21^{\circ} \mathrm{C}$ 기간) 및 $25 \sim 38 \%$ (수온 $25 ~ 28^{\circ} \mathrm{C}$ 기간) 정도 낮게 나타났다. 이러한 결과는 Fig.3에 나타낸 수온 변화에 따른 기존 $\mathrm{BAC}$ 공정과 강화 $\mathrm{BAC}$ 공정들의 손실 수두 변화결과와 매우 유 사하게 나타나고 있다. 따라서 $\mathrm{BAC}$ 부착 생물막에서 생성 되는 $\mathrm{EPS}$ 가 $\mathrm{BAC}$ 여과지의 손실 수두 유발에 큰 영향을 미 치는 것을 알 수 있다.

각각의 $\mathrm{BAC}$ 공정들 유출 및 유입수에 대한 biopolymers 농도 잔존비와 증가된 손실 수두와의 상관관계를 평가한 결 과를 Fig. 6에 나타내었다. 각각의 $\mathrm{BAC}$ 공정별로 $r^{2}$ 가 $0.82 \sim 0.87$ 로 양호한 값을 나타내었으며, 4 개의 $\mathrm{BAC}$ 공정들 의 결과를 혼합하여 평가한 경우에도 $r^{2}$ 가 0.78 로 비교적 양 호하게 나타나 부착 생물막에서 생성된 EPS가 BAC 여과지 의 손실 수두 증가에 직접적으로 영향을 미치는 것으로 평 가되었다. EPS와 같은 생체 고분자 유기물질(biopolymers) 은 용이한 생물분해능 ${ }^{32)}$ 으로 인하여 배·급수관망으로 유출

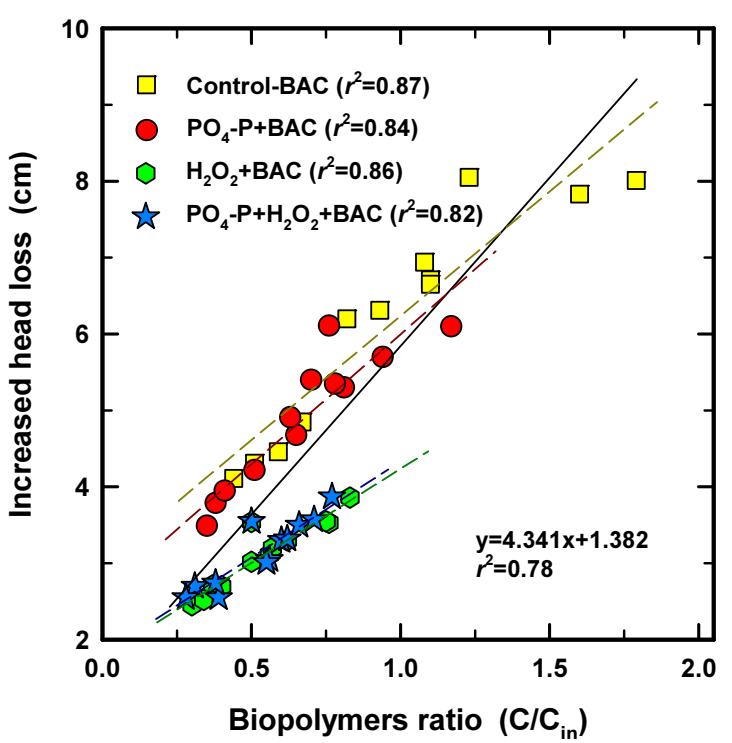

Fig.6. Correlation between biopolymers residual ratio and head loss in various BAC processes $(n=12)$.

될 경우, 관망 내에서 미생물 재성장을 유발하여 수돗물의 생물안정성(biostability)을 감소시키며 ${ }^{33,34)}$, 또한 관망에서 미생물 재성장 방지를 위해 투입하는 염소와 반응하여 인체 에 독성을 유발하는 다양한 소독부산물을 생성한다. ${ }^{35,36)}$ 이 러한 이유로 인하여 정수처리 공정의 최종 처리수에서의 biopolymers 농도관리는 매우 중요하며, 최근에는 생체 고 분자 유기물질의 저감을 위해 응집, 이온교환 수지, 막여과, 생물여과 공정 등 다양한 공정에 대한 많은 연구가 진행되 고 있다. ${ }^{37)}$

\subsection{BAC 공정별 부착 박테리아 안정도 평가}

강화 $\mathrm{BAC}$ 공정 적용성 평가에 대해 연구한 Son 등의 연 구결과 ${ }^{12}$ 에서는 생물막 부착 박테리아들의 활성도가 높을 수록 처리수에서 검출되는 총 박테리아 개체수(TCC)가 적 었으며, 비활성 박테리아에 비해 활성 박테리아의 구성비가 높은 것으로 보고하고 있다. 따라서 $\mathrm{BAC}$ 처리수 중의 $\mathrm{TCC}$ 를 분석하여 부착 박테리아 생물막의 안정도(stability)에 대 한 간접적인 평가가 가능하다.

수온 변화에 따른 생물막 부착 박테리아의 안정도 평가를 위하여 기존 $\mathrm{BAC}$ (control-BAC) 공정과 과산화수소를 투입 하는 강화 $\mathrm{BAC}\left(\mathrm{H}_{2} \mathrm{O}_{2}+\mathrm{BAC}\right)$ 공정의 처리수에 대한 $\mathrm{TCC}$ 변화 평가 결과를 Fig.7에 나타내었다.

Fig. 7에서 볼 수 있듯이 기존 $\mathrm{BAC}$ 공정의 경우, 저수온 기 $\left(8 \sim 12^{\circ} \mathrm{C}\right)$ 에는 처리수 중의 $\mathrm{TCC}$ 가 $74 \times 10^{6} \sim 98 \times 10^{6}$ cells 정도로 매우 많은 개체수가 유출되고 있으나 수온이 상승함 에 따라 점진적으로 감소하여 수온 $25 \sim 28^{\circ} \mathrm{C}$ 기간에는 처리 수 중의 $\mathrm{TCC}$ 가 $17 \times 10^{6} \sim 31 \times 10^{6}$ cells 정도로 나타나 $75 \%$ 정도 감소하였다. 이에 비해 과산화수소를 투입한 $\mathrm{BAC}$ $\left(\mathrm{H}_{2} \mathrm{O}_{2}+\mathrm{BAC}\right)$ 공정의 경우에는 저수온기에는 처리수 중의 


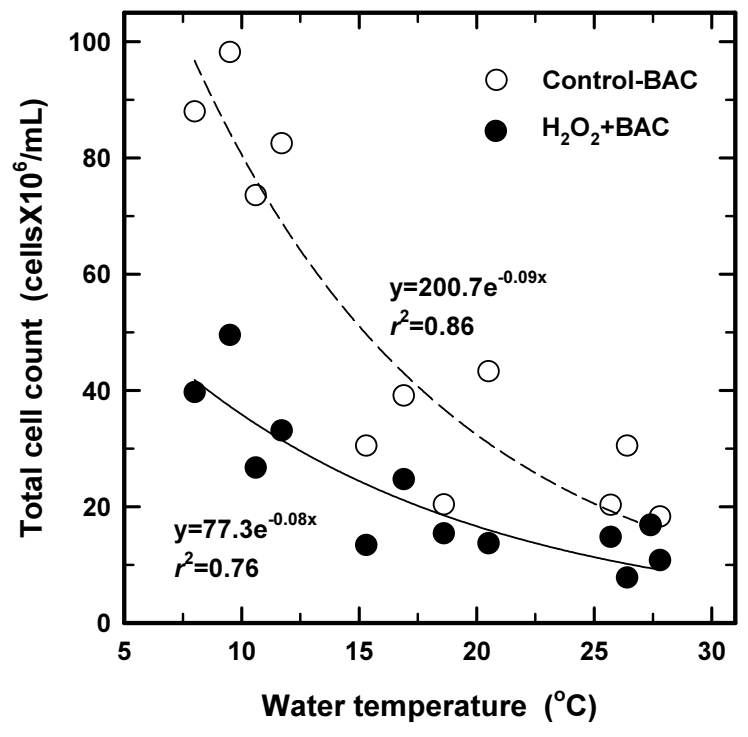

Fig. 7. Variation of total cell counts in the treated waters by various BAC processes $(n=12)$.

$\mathrm{TCC}$ 가 $27 \times 10^{6} \sim 50 \times 10^{6}$ cells 정도였으나 고수온기 $\left(25 \sim 28^{\circ} \mathrm{C}\right)$ 에는 $7 \times 10^{6} \sim 17 \times 10^{6}$ cells 범위로 조사되어 저수온기에 비해 $66 \%$ 정도 감소하였다. 저수온기에 부착 박테리아들의 높은 탈리율은 부착 박테리아의 활성도 저하에 의한 영향으로 평 가할 수 있다. ${ }^{12)}$

기존 $\mathrm{BAC}$ 공정과 강화 $\mathrm{BAC}$ 공정들의 처리수들 중의 총 박테리아 개체수(total cell count, TCC)와 총 박테리아 개체 수 중에서 활성이 있는 박테리아 개체수(live cell count, LCC) 비율에 대해 운전기간 동안 분석한 결과를 Fig. 8에 종 합하여 나타내었다. Fig. 8(a)에서 볼 수 있듯이 기존 BAC 공정의 유출수에 비하여 강화 $\mathrm{BAC}$ 공정들에서의 $\mathrm{TCC}$ 평균 값이 낮게 나타났으며, 각 공정별 유출수의 $\mathrm{TCC}$ 평균값은 control-BAC, $\mathrm{PO}_{4}-\mathrm{P}+\mathrm{BAC}, \mathrm{H}_{2} \mathrm{O}_{2}+\mathrm{BAC}$ 및 $\mathrm{PO}_{4}-\mathrm{P}+\mathrm{H}_{2} \mathrm{O}_{2}+\mathrm{BAC}$ 공정에서 각각 $46.8 \times 10^{6}$ cells, $30.3 \times 10^{6}$ cells, $21.8 \times 10^{6}$ cells 및 $18.8 \times 10^{6}$ cells로 나타났다. 강화 공정을 적용한 결과, 기 존 $\mathrm{BAC}$ 공정의 처리수에 비해 $\mathrm{TCC}$ 가 평균적으로 $35 \sim 60 \%$ 정도 낮게 검출되었다.

또한, TCC 중에서 활성 박테리아(LCC)가 차지하는 비 율을 조사한 결과(Fig. 8(b))에서는 기존 $\mathrm{BAC}$ 공정에서는 $\mathrm{LCC} / \mathrm{TCC}$ 비가 평균 0.53 정도인 반면 $\mathrm{PO}_{4}-\mathrm{P}+\mathrm{BAC}, \mathrm{H}_{2} \mathrm{O}_{2}+\mathrm{BAC}$ 및 $\mathrm{PO}_{4}-\mathrm{P}+\mathrm{H}_{2} \mathrm{O}_{2}+\mathrm{BAC}$ 공정에서는 각각 $0.84,0.87$ 및 0.89 로 나타나 생물막에서 탈리되는 박테리아의 대부분이 활성 박테리아로 평가되었다. 특히, 저수온기 $\left(8 \sim 12^{\circ} \mathrm{C}\right)$ 에는 기존 $\mathrm{BAC}$ 공정에서는 $\mathrm{LCC} / \mathrm{TCC}$ 비가 0.33 으로 강화 $\mathrm{BAC}$ 공정 들의 $0.76 \sim 0.83$ 과 비교하여 큰 차이를 나타내었다. 따라서, 기존 $\mathrm{BAC}$ 공정에 비해 강화 $\mathrm{BAC}$ 공정들의 경우, 부착 생 물막에서 탈리되는 박테리아의 개체수도 적을 뿐만 아니라 대부분이 활성 박테리아로 평가되어 수온 변화 등 다양한 스트레스 요인에도 생물막이 안정적으로 유지되는 것으로
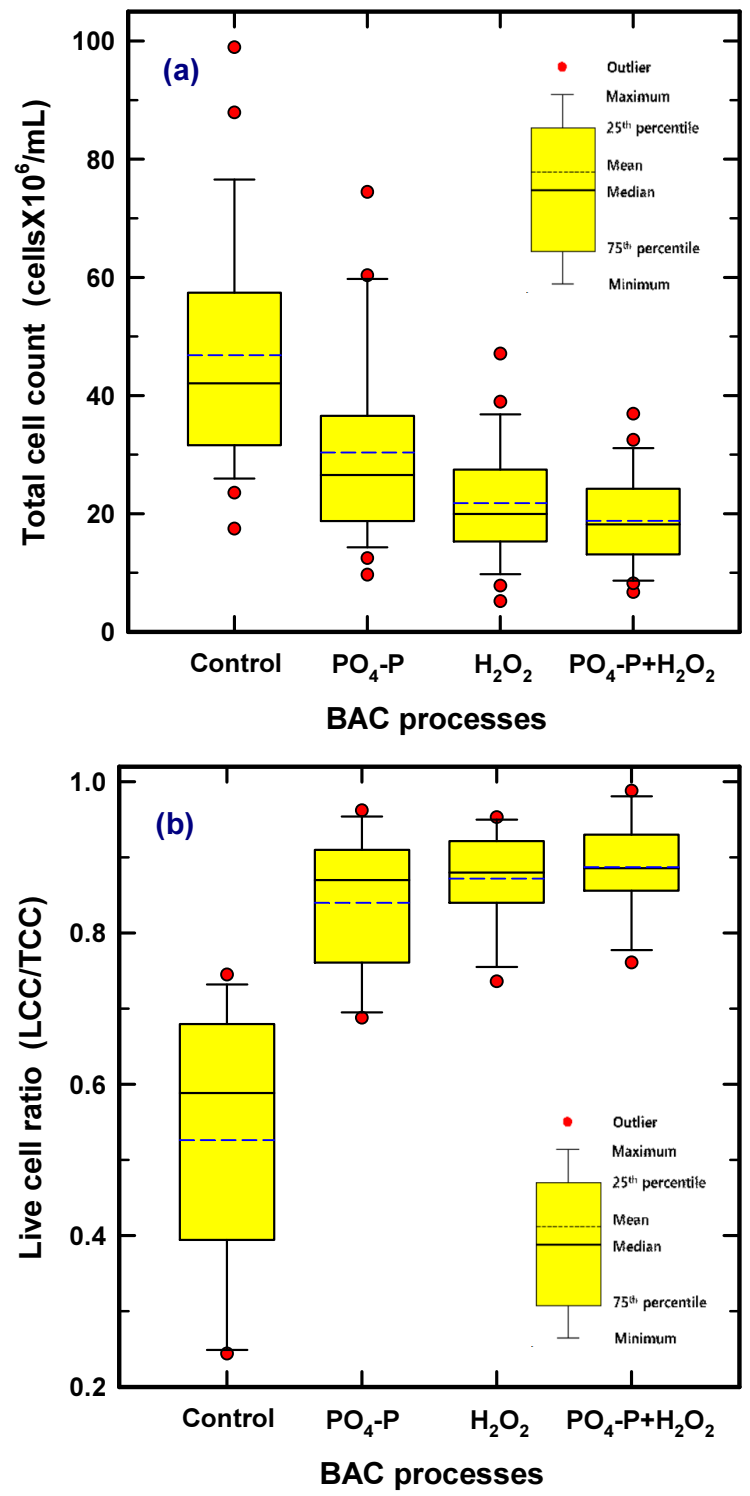

Fig. 8. Variation of total cell counts (a) and live cell ratio (b) in the treated waters of various BAC processes $(n=12)$.

평가되었다.

\section{4. 결론}

운전기간 동안 기존 $\mathrm{BAC}$ (control-BAC) 공정에 비하여 인과 과산화수소를 투입한 강화 $\mathrm{BAC}$ 공정들에서 손실 수 두 저감효과가 뚜렷하게 나타났다. 특히, 인을 투입한 경우 보다 과산화수소를 투입한 경우에 손실 수두 저감효과가 높 았다. 저수온기에 강화 $\mathrm{BAC}$ 공정들에 비하여 control-BAC 에서의 급격한 손실 수두 증가는 생물막에서의 다량의 EPS 생성으로 인한 결과이며, 인이나 과산화수소 투입으로 부착 생물막의 안정도(stability) 향상 및 EPS 생성량을 저감시켜 손실 수두를 감소시킬 수 있었다. 


\section{References}

1. C. D. Seo, H. J. Son, J. T. Choi, D. C. Ryu, P. J. Yoo, Occurrence of organophosphorus flame retardants (OPFRs) in Nakdong River basin: main streams, tributaries and STP effluents, J. Korean Soc. Environ. Eng., 37(7), 396-403(2015).

2. C. D. Seo, H. J. Son, J. T. Choi, P. J. Yoo, S. H. Jang, Occurrence of UV filters in Nakdong River basin: main streams, tributaries and STP effluents, J. Korean Soc. Environ. Eng., 37(8), 472-479(2015).

3. H. S. Yoom, H. J. Son, H. Y. Kim, D. C. Ryu, J. D. Shin, Y. H. Lee, C. W. Kim, Occurrence characteristics of parabens in Nakdong River basin, J. Korean Soc. Environ. Eng., 40(5), 193-202(2018).

4. C. D. Seo, H. S. Yoom, M. J. Song, K. A. Kim, S. Y. Kim, H. Son, Occurrence and behavior of residual pharmaceuticals in the Nakdong River basin, J. Korean Soc. Environ. Eng., 42(4), 177-187(2020).

5. J. Ra, H. Yoom, H. Son, Y. Lee, Occurrence and transformation of gabapentin in urban water quality engineering: rapid formation of nitrile from amine during drinking water chlorination, Water Res., 184, 116123(2020).

6. H. J. Son, S. J. Yoo, J. S. Roh, P. J. Yoo, Biological activated carbon (BAC) process in water treatment, J. Korean Soc. Environ. Eng., 31(4), 308-323(2009).

7. R. Ahmad, A. Amirtharajah, A. Al-Shawwa, P. M. Huck, Effects of backwashing on biological filters, J. Am. Water Works Assoc., 90(12), 62-73(1998).

8. S. G. Kim, H. G. Park, H. J. Son, H. S. Yoom, D. C. Ryu, Evaluation of influence factors for determination of proper backwashing time of biological activated carbon (BAC) process in drinking water treatment process, J. Environ. Sci. Int., 24(12), 1551-1558(2015).

9. J. C. Goldgrabe, R. S. Summers, R. J. Miltner, Particle removal and head loss development in biological filters, J. Am. Water Works Assoc., 85(12), 94-106(1993).

10. C. Lauderdale, P. Chadik, M. J. Kirisits, J. Brown, Engineered biofiltration: enhanced biofilter performance through nutrient and peroxide addition, J. Am. Water Works Assoc., 104, E298-E309(2012).

11. J. H. Noh, S. H. Yoo, H. Son, K. E. Fish, I. Douterelo, S. $\mathrm{K}$. Maeng, Effects of phosphate and hydrogen peroxide on the performance of a biological activated carbon filter for enhanced biofiltration, J. Hazard. Mater., 388, 121778(2020).

12. H. Son, E. Y. Jung, H. S. Yoom, S. G. Kim, S. K. Maeng, Application of enhanced BAC process for improving drinking water treatment efficiency, J. Korean Soc. Environ. Eng., 42(6), 298-307(2020)

13. S. E. Keithley, M. J. Kirisits, Enzyme-identified phosphorus limitation linked to more rapid headloss accumulation in drinking water biofilters, Environ. Sci. Technol., 53, 2027-2035(2019).

14. M. W. LeChevallier, W. Schulz, R. G. Lee, Bacterial nutrients in drinking water, Appl. Environ. Microbiol., 57(3), 857-862(1991).
15. D. L. Pardieck, E. J. Bouwer, A. T. Stone, Hydrogen peroxide use to increase oxidant capacity for in situ bioremediation of contaminated soils and aquifers: a review, J. Contaminant Hydrol., 9(3), 221-242(1992).

16. B. E. Christensen, H. N. Trønnes, K. Vollan, O. Smidsrød, R. Bakke, Biofilm removal by low concentration of hydrogen peroxide, Biofouling, 2(2), 165-175(1990).

17. E. Neyens, J. Baeyens, M. Weemaes, B. De Heyder, Advanced biosolids treatment using $\mathrm{H}_{2} \mathrm{O}_{2}$ oxidation, Environ. Eng. Sci., 19(1), 27-35(2002).

18. S. Velten, F. Hammes, M. Boller, T. Egli, Rapid and direct estimation of active biomass on granular activated carbon through adenosine tri-phosphate (ATP) determination, Water Res., 41, 1973-1983(2007).

19. H. J. Son, J. K. Lee, S. G. Kim, H. K. Park, E. Y. Jung, Removal characteristics of geosmin and MIB in BAC process : biodegradation and adsorption, J. Korean Soc. Environ. Eng., 39(6), 318-324(2017).

20. S. A. Huber, A. Balz, M. Abert, W. Pronk, Characterisation of aquatic humic and non-humic matter with size-exclusion chromatography-organic carbon detection-organic nitrogen detection (LC-OCD-OND), Water Res., 45, 879-885(2011).

21. I. W. Sutherland, Exopolysaccharides in biofilms, flocs, and related structures, Water Sci. Technol., 43(6), 77-86(2001).

22. L. Mauclaire, A. Schurmann, M. Thullner, S. Gammeter, J. Zeyer, Sand filtration in a water treatment plant: biological parameters responsible for clogging, J. Water Supply Res. Technol.-Aqua, 53(2), 93-108(2004).

23. Z. Wang, Z. Wu, S. Tang, Extracellular polymeric substances (EPS) properties and their effects on membrane fouling in a submerged membrane bioreactor, Water Res., 43, 2504-2512(2008).

24. S. Rinck-Pfeiffer, S. Ragusa, P. Sztajnbok, T. Vandevelde, Interrelationships between biological, chemical, and physical processes as an analog to clogging in aquifer storage and recovery (ASR) wells, Water Res., 34, 2110-2118(2000).

25. E. Neyens, J. Baeyens, M. Weemaes, B. De Heyder, Advanced biosolids treatment using $\mathrm{H}_{2} \mathrm{O}_{2}$ oxidation, Environ. Eng. Sci., 19(1), 27-35(2002).

26. H. J. Son, Y. S. Kim, S. G. Kim, Y. D. Hwang, I. S. Hwang, Insight into biodegradation of dissolved organic matter fractions using LC-OCD-OND in drinking water treatment processes, J. Korean Soc. Environ. Eng., 41(1), 55-60(2019).

27. H. Son, H. S. Yoom, C. D. Seo, S. G. Kim, Y. S. Kim, Evaluation of dissolved organic matter removal characteristics in GAC adsorption process in drinking water treatment process using LC-OCD-OND, J. Korean Soc. Environ. Eng., 42(5), 239-250(2020).

28. M. Kirisits, A. Evans, C. Lauderdale, Effect of phosphorus limitation on the production of extracellular polymeric substances (EPS) by drinking-water bacteria, Proceedings of Biological Treatment Symposium, Denver, CO, USA, pp. 59-63(2013).

29. R. Boonchai, J. Kaewsuk, G. Seo, Effect of nutrient 
starvation on nutrient uptake and extracellular polymeric substance for microalgae cultivation and separation, Desali. Water Treat., 55, 360-367(2015).

30. S. Liu, C. Gunawan, N. Barraud, S. A. Rice, E. J. Harry, R. Amal, Understanding, monitoring, and controlling biofilm growth in drinking water distribution system, Environ. Sci. Technol., 50, 8954-8976(2016).

31. S. E. Keithley, M. J. Kirisits, Enzyme-identified phosphorus limitation linked to more rapid headloss accumulation in drinking water biofilters, Environ. Sci. Technol., 53, 2027-2035(2019).

32. F. Chen, S. Peldszus, A. M. Elhadidy, R. L. Legge, M. I. Van Dyke, P. M. Huck, Kinetics of natural organic matter (NOM) removal during drinking water biofiltration using different NOM characterization approaches, Water Res., 104, 361-370(2016).

33. A. Sathasivan, I. Fisher, T. Tam, Onset of severe nitrification in mildly nitrifying chloraminated bulk waters and its relation to biostability, Water Res., 42, 3623-3632(2008).

34. K. C. B. Krishna, A. Sathasivan, D. C. Sarker, Evidence of soluble microbial products accelerating chloramine decay in nitrifying bulk water samples, Water Res., 46, 3977-3988 (2012).

35. J. L. Liu, X. Y. Li, Y. F. Xie, H. Tang, Characterization of soluble microbial products as precursors of disinfection byproducts in drinking water supply, Sci. Total Environ., 472, 818-824(2014).

36. S. Wang, T. Lin, W. Chen, H. Chen, Optimization of the precursor removal of dichloroacetonitrile (DCAN), an emerging nitrogenous disinfection by-products, in an up-flow BAC filter, Chemosphere, 189, 309-318(2017).

37. H. Shen, X. Tang, N. Wu, H. Chen, Leakage of soluble microbial products from biological activated carbon filtration in drinking water treatment plants and its influence on health risks, Chemosphere, 202, 626-636(2018).

\section{Authors}

\section{Heejong Son}

Water Quality Institute, Busan Water Authority, Researcher, ORCID(D) 0000-0002-7950-8223

\section{Eun-Young Jung}

Water Quality Institute, Busan Water Authority, Researcher, ORCID(i) 0000-0003-4053-7585

\section{Hee-Young Kim}

Water Quality Institute, Busan Water Authority, Researcher, ORCID(D) 0000-0001-7350-3264

\section{Sang-Goo Kim}

Water Quality Institute, Busan Water Authority, Researcher, ORCID(1) 0000-0003-4977-8684 